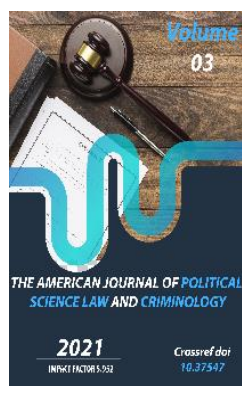

\title{
Issues Of Improving Civil Litigation
}

\author{
Quchqarov Xamidullo \\ Doctor Of Philosophy In Law (PhD) Teacher At The Lawyers' Training Center Under The \\ Ministry Of Justice Of The Republic Of Uzbekistan
}

Copyright: Original content from this work may be used under the terms of the creative commons attributes 4.0 licence.

\section{ABSTRACT}

This article presents the specifics, advantages and disadvantages of considering labor disputes in court and out of court, as well as suggestions for improving the norms governing the existing situation in our legislation in this regard.

\section{KEYWORDS}

Employee, employer, court, judge, trade union, term, state duty, decision, ruling, labor dispute, commission, executive document.

\section{INTRODUCTION}

The main purpose of the introduction of modern information and communication technologies in the judiciary is to ensure openness, transparency and efficiency of the judiciary, increase the quality of court proceedings and access to justice.
The role of the courts among the national institutions for the protection of human rights is of special importance in ensuring the rights and freedoms, the legitimate interests of citizens and in this regard, along with other areas, effective reforms are being carried out in 
the judiciary. In particular, the Resolution of the President of the Republic of Uzbekistan dated August 30, 2017 "On measures to further improve the introduction of modern information and communication technologies in the judiciary". Based on this decision, the creation of a modern information and communication infrastructure in the judicial system, the development of information resources and information systems, the introduction of electronic document management systems and the provision of interactive services to citizens through the websites of judicial authorities in connection with the application of information and communication technologies which allows you to do your work quickly and easily, without unnecessary hassle.

Also, in order to further strengthen the positive results of these changes, further improve the judicial activity and the widespread introduction of modern information and communication media, on September 3, 2020 the President of the Republic of Uzbekistan adopted a resolution "On measures to digitize the judiciary"[1]. The resolution noted that the exchange of information with ministries and agencies in the course of court proceedings is carried out mainly in paper form. The existence of such a procedure in itself requires more time to make a final decision on the case, which leads to a faster resolution of disputes by the courts and an increase in the volume of cases considered by the court. In his Address to the Oliy Majlis on December 29, 2020, the President noted that the effectiveness of our reforms is closely linked with the ongoing reforms in the judicial sphere and said: "As you know, judicial reform over the past 4 years. We have taken bold steps in this regard. More than 40 laws, decrees and decisions have been adopted on priority issues in this area. Justice is a solid foundation of statehood. The judiciary plays a key role in ensuring justice and the rule of law. From this perspective, we still have a lot of work to do in this regard.

The digitalization of the judiciary will be further expanded, allowing our citizens to apply "online" without having to go to the courthouse and citizens will be able to monitor the processing of their applications remotely"[2] noted.

Of course, as a result of the above reforms, there is an optimization of the judicial procedure in civil proceedings. It should be noted that the optimization of judicial proceedings is directly related not only to the involvement of information technology in the process of applying regulatory mechanisms, but also to the process of unification of normative legal acts. Researcher E.A.Tsaregorodtseva notes that the simplification of litigation is also achieved through the unification of normative documents[3].

The outcome of any reform will depend directly on the knowledge and skills of the applicant and this will require the courts to apply not only the ability to use modern media but also the clear and uniform application of the requirements established by law. Only then will the decision-making process and decisions made at the end of the process, carried out with the help of information technology, serve to be lawful, fair and reasonable, which means that the set tasks and goals can be achieved only when the mechanisms and legislation are harmonized.

A separate and comprehensive type of civil process is labor disputes, as employment is a 
constitutional right of everyone and Article 37 of the Constitution of the Republic of Uzbekistan states that everyone has the right to work, to free choice of job, to just and favorable conditions of work and to protection from unemployment.

A number of mutually beneficial projects are being implemented in our country with international organizations to create new jobs. In particular, in December 2020, on the basis of a project of the Ministry of Employment and Labor Relations, the Asian Development Bank approved a loan of $\$ 93$ million for a project aimed at reducing unemployment in Uzbekistan[4]. According to the project, developed jointly by the Ministry of Employment and Labor Relations and the Ministry of Higher and Secondary Special Education, 60,000 citizens, including 48,000 unemployed people, will have the opportunity to improve their professional skills.

At the same time, such issues are relevant and the problem in this process is not only the increase in unemployment due to lack of jobs, but also the unjustified dismissal of employed citizens. As a result, there are many disputes between employers and employees over the issue of reinstatement. The fact that there are a number of problems in seeing these types of disputes in the courts prevents them from being resolved properly and fairly.

In particular, the fact that labor disputes related to the termination of the employment contract are subject only to the courts, which means that such disputes are seen only in civil cases, imposes a greater responsibility on the part of the courts.

As a general rule, labor disputes have specific features of labor dispute resolution (pre-trial and out-of-court) and are considered by the Judicial and Labor Disputes Commission, so in this article we present some of our author's suggestions and conclusions on the existing problems in this regard.

An important procedural feature of the preparation of labor disputes for trial is the introduction of special deadlines for the preparation of this category of cases for trial. In particular, in accordance with Article 202 of the Criminal Procedure Code, the preparation of civil cases for trial must be carried out no later than ten days from the date of receipt of the application and the initiation of civil proceedings. In some cases, this period may be extended to twenty days by a reasoned ruling of a judge on extremely complex cases, including claims for alimony, compensation for disability or other damage to health, as well as the death of a breadwinner, as well as labor relations, except for cases on.

It should be noted that there are specific procedural features in the timing of court proceedings in cases arising from labor relations. In particular, according to Article 207 of the Criminal Procedure Code, labor cases must be considered by the court of first instance no later than twenty days from the date of preparation for trial. The establishment of such a requirement in the legislation implies the prompt protection of the violated rights of the parties to the employment relationship through the courts. However, it should be noted that the fulfillment of the above task can be achieved when the requirement of this norm is fully complied with by the courts with other requirements of substantive law. Because no matter what law is enshrined in law, failure to comply with substantive or procedural law during the proceedings will 
lead to an increase in the time and expense of the parties to the dispute in the future. In particular, a collective contract or collective bargaining agreement provides for the prior consent of a trade union committee or other employee representative body to terminate an employment contract at the initiative of the employer, but in some cases this rule is enforced and non-compliance leads to further confusion. For example, G.M. filed a lawsuit against the defendant institute, finding the order of the rector of the institute to be illegal, revoking it and reinstating him in the job, collecting wages and moral damages for the days of compulsory probation.

The lower courts' decisions denied the claim.

The plaintiff's claim for annulment of the order to terminate the employment contract, reinstatement and recovery of wages for the days of compulsory termination as a basis for non-compliance with a number of norms of labor law in his dismissal, the joint trade union committee of the institute no consent was obtained, and he was not notified in writing of the date and place of the meeting.

In dismissing the claim, the lower courts relied on the fact that the order to terminate the employment contract with the plaintiff was legally issued. Paragraph 9.2 of the Model Regulations on the organization of primary trade unions in the system of the Federation of Trade Unions of Uzbekistan, approved by the Presidium of the Council of the Federation of Trade Unions of Uzbekistan on January 26, 2013 No 9-15, within the powers of the primary trade union committee it is noted that whether or not to agree to terminate the employment contract with the employee will resolve the issue between the administration of the institute and the trade union organization.
Clause 3.4 of the collective agreement for 20172020 stipulates that the termination of the employment contract at the initiative of the employer can be done only with the prior consent of the trade union committee.

The Board of the Joint Trade Union Committee of the Institute of Education, Science and Culture of March 12, 2018, No 1-3 "O" agreed to terminate the employment contract with the plaintiff.

However, the Civil Court of the Supreme Court concluded that the law explicitly provides for the consent of a trade union to terminate an employment contract at the initiative of the employer, in which case the union delegates the statutory authority to the presidium on the basis of the minutes of the trade union committee meeting.

According to Article 100 of the Labor Code of the Republic of Uzbekistan, termination of both an employment contract for an indefinite period and a fixed-term employment contract at the initiative of the employer must be justified.

Accordingly, the Civil Court Judicial Panel ruled that the employment contract with the plaintiff was terminated in violation of labor law and by its ruling of July 30, 2019, annulled the court documents and issued a new decision to satisfy the plaintiff's claim[5].

Another problem in our legislation in this regard is that in accordance with the requirements of Article 184 of the Code of Administrative Offenses, a court ordering the termination of an employment contract or reassignment of an employee whose employment contract has been illegally terminated or who has been illegally transferred to another job as a third party, the 
defendant must be involved on his own initiative to participate in the case. Because in most cases, employers terminate employment contracts with employees who do not meet their personal interests or illegal requirements in violation of the law. However, in accordance with the requirements of paragraph 52 of the 12th decision of the Supreme Court of the Republic of Uzbekistan "on the application of laws regulating the termination of the employment contract by the courts"dated 17 April 1998, the issue of attracting an official who has carried out the termination of an employment contract or the transfer of an employee, this issue can also find its solution in the process of being seen in the courtroom of the case. Such involvement of an official shall not deprive him of the right to speak as a representative of the defendant in the case. If an official who has been duly notified of the time and place of the hearing does not appear in the courtroom for unjustified reasons or is not informed of the reasons for his absence, the court may hear the case without his presence[6].

It follows from the above that the involvement of an official in the case remains at the discretion of the court, although the requirements of Article 184 of the CPC are conditional, so it is advisable to bring paragraph 54 of the Plenum decision into line with Article 184 of the CPC to prevent further recourse, would have done.

In the experience of developed foreign countries, the most appropriate tool in the settlement of labor disputes in the courts is mainly the conclusion of a settlement agreement, which serves to reduce court costs. Another feature of our labor disputes is the non-collection of state duties from the plaintiff. In accordance with Article 19 of the Law of the Republic of Uzbekistan "On State Duty", if the plaintiff is exempted from paying state duty, the state duty is collected from the defendant

(if he is not exempted from paying state duty) in accordance with the amount of the claim. There is no provision in this article or any other norm for the refund of a certain part of the state duty if the parties enter into an amicable agreement. This is one of the circumstances that prevents the parties from reaching an agreement, albeit in part.

As mentioned above, labor disputes can be considered not only by the courts but also by the labor dispute commission, where the question of which labor disputes are directly subject to the court is determined by law. Admittedly, although the Labor Code regulates the powers of the labor dispute commission and the settlement of disputes on the basis of the rules set out in Articles 262-267, in practice it is not possible to ensure the activities of this body and the legal force of its decision. This is directly related to the lack of a direct body to organize the work of the labor dispute commission, at least its activities are not coordinated by its higher bodies, such as a trade union committee, or its activities are not controlled by a specially authorized body (for example, the Ministry of Employment and Labor Relations). Second, the lack of a separate normative document guaranteeing the labor rights of members of the labor disputes commission, as stipulated in the Labor Code and the Law on Trade Unions, guarantees the future employment of trade union committee members, as well as their legal knowledge. The main reason is that in any case, the members of the commission are both 
materially and morally dependent on the employer. In addition, the fact that the decision made by them is not binding on the employer also creates the same negative conditions as above.

A number of scholars have made proposals to improve the procedure for resolving labor disputes in court, including M.M. Mamasiddikov, who has raised the issue of specialization of courts and the establishment of separate courts for labor disputes. In his opinion, the establishment of special labor courts to resolve disputes arising from labor relations is an important factor in the effective protection of the legitimate rights and interests of citizens[7]. Without denying Mamasiddikov's views, the specialization of courts is a complex process in terms of time and money, as well as the fact that court proceedings depend not only on the procedure, but also on the knowledge and skills of judges. We argue that the formation of a separate corps of judges is expedient. In this case, the judge will be able to constantly master the regulations governing labor disputes and the mechanisms for their implementation in practice and improve their practical skills in this area. In this way, in the future, we will be able to create a collegial system of judges who will look into labor disputes, such as France and Germany, that is, judges who are represented by employers and employees.

At the same time, one of the factors that negatively affects the improvement of reforms in the short-term review of cases in civil proceedings is the gaps identified in the

\footnotetext{
${ }^{1}$ On amendments and additions to the Civil Procedure Code of the Republic of Kazakhstan on the implementation of modern formats of the work of
}

mechanisms for the implementation of the law. In particular, in accordance with Articles 17-18-19 of the Law of the Republic of Uzbekistan "On amendments and additions to some legislative acts of the Republic of Uzbekistan in connection with the improvement of the activities of certain state bodies and organizations"[8]

No. 536 of May 10, 2019, the fifth part of Article 165 of the EPC. The first sentence and the first sentence of the fourth part of Article 143 of the Code of Administrative Procedure were amended to read that "participants in court proceedings and those present in the courtroom have the right to make written notes, transcripts and audio recordings". The amendment to the new version of the Code stipulates that in 2018 the "right to make written notes" $\left[{ }^{1}\right]$ is the right of those present in the courtroom. In this regard, in accordance with Article 23 of the Law of the Republic of Kazakhstan "On Improving the Activities of Courts and Prevention of Excessive Expenses" of June 10, 2020 No. 342-VI, a new Code of Civil Procedure "Electronic Protocol" Article 133-4 was introduced and it is now stipulated that audio and video recordings be recognized as electronic minutes in court proceedings. In our opinion, in the civil justice system of our country, participants in civil proceedings, as well as participants in economic proceedings and administrative proceedings, should have the right to transcripts and audio recordings, to avoid time and unnecessary costs in the process.

courts, reduction of unnecessary court procedures and costs. June 10, 2020 No. 342-VI ZRK 


\section{REFERENCES}

1. National Database of Legislation, 04.09.2020, No. 07/20/4818/1255

2. Address of the President of the Republic of Uzbekistan Shavkat Mirziyoyev to the Oliy Majlis. The word of the people. December 30, 2020, №276 (7778)

3. E.A. Tseregorodtseva. Reforming the simplified procedure: objectives and results / Arbitration and civil procedure. No. 11/2020. -S.29-30.

4. https://xs.uz. December 14, 2020.

5. Judicial practice on cases considered by the Judicial Board on Civil Cases of the Supreme Court of the Republic of Uzbekistan in the third quarter of 2019 in the supervisory procedure Case No. 6-1154-19.

6. Paragraph 52 of the Resolution of the Plenum of the Supreme Court of the Republic of Uzbekistan No. 12 of April 17, 1998 "On the application by courts of the laws governing the termination of an employment contract"

7. Mamasiddiqov M.M. Procedural features of litigation of disputes arising from labor legal relations. Dissertation for the degree of Candidate of Legal Sciences. T .: 2002. - 16 p.

8. National Database of Legislation, 11.05.2019, No. 03/19/536/314; 20.10.2020,03/20/642/1396

9. On amendments and additions to the Civil Procedure Code of the Republic of Kazakhstan on the implementation of modern formats of the work of courts, reduction of unnecessary court procedures and costs. June 10, 2020 No. 342-VI ZRK 